金属接触型すべり免震支承の摩擦係数の同定と応答低減効果

\title{
IDENTIFICATION OF THE FRICTIONAL COEFFICIENT OF THE METAL-TOUCHED TYPE OF BASE-ISOLATOR AND VERIFICATION OF ITS RESPONSE REDUCTION
}

\author{
西 村 春 美*, 安部 祥子**, 橘 英三郎*** \\ Harumi NISHIMURA, Shoko ABE and Eizaburo TACHIBANA
}

\begin{abstract}
The sliding bearings are used for lightweight structures instead of the laminated rubber bearings. In many studies, the frictional coefficients of sliding bearings are assumed as less than 0.10 . However, even if frictional coefficient is about 0.20 , it may be effective for a big earthquake (Max. acceleration $>200 \mathrm{Gal}$ ). In this study, the efficiencies of sliding bearings made of stainless steel are examined. The static and the dynamic frictional coefficients were identified about 0.20 and 0.10 , respectively. It demonstrated experimentally and analytically that the inter-story displacements decreased to $25 \sim 50 \%$.
\end{abstract}

Keywords: Base isolation, Metal-touched slide type, Experimental testing, Frictional coefficient,

Identification, Simulation

免震、金属接触すべり形式、実験、摩擦係数、同定、シミュレーション

\section{1 .はじめに}

免震構造において積層ゴム支承を用いた場合、十分な免震効果を得 るためには、支承部の面圧が $10 \mathrm{MPa}$ 程度必要となるため、中低層の軽 量構造物には鋼球を用いた転がり支承や10MPa以下でも有効となるす ベり支承がしばしば用いられる。転がり支承については既に数多くの 建物に導入されており、その有効性も確かめられているが鋼球の接触 点において応力集中が常時生じているため、直下型地震などによる大 きな上下動に対しての安全性にやや不安を残している。すべり支承に ついてはすべり面における摩擦保数について実験的、解析的研究がな され ${ }^{1-3)}$ 、面圧、速度及び振幅などに依存することが知られている。す ベり支承の性能はすべり面の摩擦倸数が小さい程良いとされ、通常、 0.01 0.1程度の摩擦係数を有するテフロンなどがすべり面として用い られる。しかし、耐久性やクリープなどの面でまだ解決すべき問題点 も少なからず残している。

筆者らは将来において低価格化が期待できるすべり型免震支承に着 目し、摩擦保数が 0.001 0.5 の場合についてのすべり支承による大域 的な範囲における応答低減効果を 3 次元有限要素法を用いて調べ4)、 摩擦係数が 0.2 前後でも大規模な地震に対してかなりの応答低減効果 の得られることが分かった。これは入力地震の水平加速度が200Galを 越える場合にすべりが発生し、上部への水平加速度の伝達を抑える効
果があることを再確認した結果となった。ところでステンレスの摩擦 係数はおおよそ 0.2 前後であることは知られており、もしステンレス 同士によるすべり支承が有効であることが確認され、実用化されれば 低価格の免震構造を実現する事ができる。しかしながら摩擦といった 現象は一般に多くの因子に依存しており、実用化の為には摩擦係数の 同定などを通じての詳細な検討がなされる必要がある。金属同士の摩 擦係数については一定圧で締め付けた後、定常綝り返し荷重による押 し引き実験により調べられている5。これらはボルトによる摩摖接合 などにおいて有効であるが、しかし建築構造物でのすべり支承を対象 とする場合はすべり面において浮き上がりによる離間が発生する事も 考えられ、これらも考虑した上でより害際に近い条件で摩擦係数を同 定する必要がある。

こうした考えの基にステンレス製の台車をステンレス製の水平すべ り台の上に載せ、水平漸增荷重および水平一定荷重による実験を行 い、上下動や潤滑剤が摩擦係数に及ぼす影響を調べた6)。その結果、最 大静止摩擦保数が約 0.2 程度であることを確かめる事が出来た。また 上下動や潤滑剤が摩擦係数に及ぼす影響についてはバラツキが大きく 定性的、定量的に把握することが困難であった。その理由としては、 すべり台の長さが十分でなかった為、台車の滑走時間が 1 秒以内であ り、滑走時におけるサンプリング数が少ない事も同定結果に大きなバ
* 大阪大学大学院工学研究科建築工学専攻 大学院生・工修

** 大阪大学大学院工学研究科建築工学専攻 大学院生

**** 大阪大学大学院工学研究科建築工学專攻 教授. 工博
Graduate Student, Architectural Engineering Osaka University, M. Eng. Graduate Student, Architectural Engineering Osaka University Prof., Architectural Engineering Osaka University, Dr. Eng. 
ラツキが生じた原因と考えられる。次に地震動入力による実験を行 い、台車の応答加速度が当初予想した通り200Gal以内に抑えられると いう結果を得た。さらに実験で観測された変位応答を用いて摩擦係数 を同定し、静止摩擦係数 $\mu_{s}=0.17 \sim 0.21$ 及び動摩擦係数 $\mu_{d}=0.11 \sim 0.16$ を 得た。これらの同定された摩擦係数を用いて多質点系の応答解析を行 うことにより応答低減効果を調べ、すべり支承を用いた場合の水平層 間変位が非免震の場合の $20 \%$ 50\%に低減することが分かった7)。お これらの実験では有明工業尃門学校の装置を用いている。

本研究では、2003 年 2 月に大阪大学に設置された高精度の動電式2 軸同時型地震動再現装置により引き続きステンレス製の台車を用いて 摩擦係数の面圧依存性を調べる実験を行うとともに摩擦係数を同定す る。さらに3層フレームをすべり支承の上に載せた実験を行い、ステ ンレスのすべり支承による応答低減効果を調ベ、シミュレーション結 果との整合性について検討する。

\section{2. 剛体モデルを用いた振骬実硂}

\section{2-1 実験装圆}

動電式 2 軸同時型地震動再現装㯰(株式会社振研製、最大变位士 $10 \mathrm{~cm}$ )に着脱式すべり面（ステンレス製）を有するカイイドテーブルを 固定し、すべり面の上に台車 (ステンレス製) を載せた装置を用いる （Fig. 1）。接触面の面圧を高めるため、3つの円錐台状の突起(総接触 面積 $1 \mathrm{~cm}^{2}$ )を台車の下面に設けている(Fig. 2)。台車の上に鉄製の錘(1 枚につき約 $100 \mathrm{~N})$ を複数枚載せることにより台車の重量は 120.6 509.4N の 5 段階に変化できる(Table 1)。相対運動する材料表面の損傷 を防止および摩擦や摩耗を低隇する為、潤滑剤として有機モリブデン （モリコンク F100）を用いた。

\section{2-2 実験条件と実験方法}

入力する地震波は振動台の変位の制限により、時間軸を半分に圧縮 した修正JMA KOBE NS波(最大加速度 $=818 \mathrm{Gal}$ ) と修正JMA KOBE EW 波 $($ 最大加速度 $=617 \mathrm{Gal}) 、$ 時間軸を半分に圧維しさらに加速度を元の 2 倍にした修正El Centro NS 波(最大加速度=683Gal)を用いた。また同時

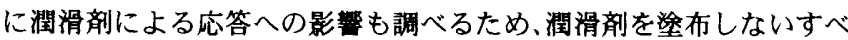
り面と筀布したすべり面の 2 種類を用いた。入力波、すべり面、台車 の重量の条件をパラメータとし、30ケース(Table 2)について3回ずつ 繰り返し実験を行い、加速度計及びレーザー変位計により、振動台と 台車の加速度、振動台の変位、振動台と台車の相対変位を計測した。

\section{2-3 実験結果及び考察}

修正JMA KOBE NS波を入力した場合の振動台の加速度と台車の加 速度を表すグラフの一例を Fig. 3 およびFig. 4 に示す。Fig. 3 は台車の 重量が $120.6 \mathrm{~N}$ (面圧 1.2MPa相当)における潤滑剤有無による比較、Fig. 4は台車の重量が509.4N(面圧5.1MPa相当)における潤滑剤有無による 比較である。面圧が低い場合、台車の加速度は潤滑剤の有無に関わら ず、瞬間的に大きな加速度が生じる部分があるものの全般的に台車の 応答加速度は $200 \mathrm{Gal}$ 以内である。一方面圧が高い場合、潤滑剤を塗布 しないすべり面の台車の加速度は面圧が低い場合と特に変化しないの に対し、塗布したすべり面は面圧が高くなると台車の加速度が全般的 に小さくなった。Fig. 5 および Fig. 6 に修正 JMA KOBE NS 波を入力 した場合の振動台の変位、台車の変位、振動台と台車の相対変位を表 すグラフの一例を示す。振動台と台車の相対変位はすべり量を意味
し、最大加速度の発生する2 2.5秒に大きなすべりが生じ、 5 秒以降は ほとんどすべりは生じていない。潤滑剤の有無によりすべり量に差が 見られ、潤滑剤を塗布しないすべり面では最大で8 $\mathrm{cm}$ 程度であるのに 対し、塗布したすべり面では $15 \mathrm{~cm}$ 程度であった。また台車の重量の 相違によるすべり量の違いはほとんど見られなかった。実験結果のま とめを Table 3 に示す。Table 3 より 120.6 509.4N の間ではすべり量は 台車の重量の影響をほとんど受けないこと、加速度の RMS 值比[=(台

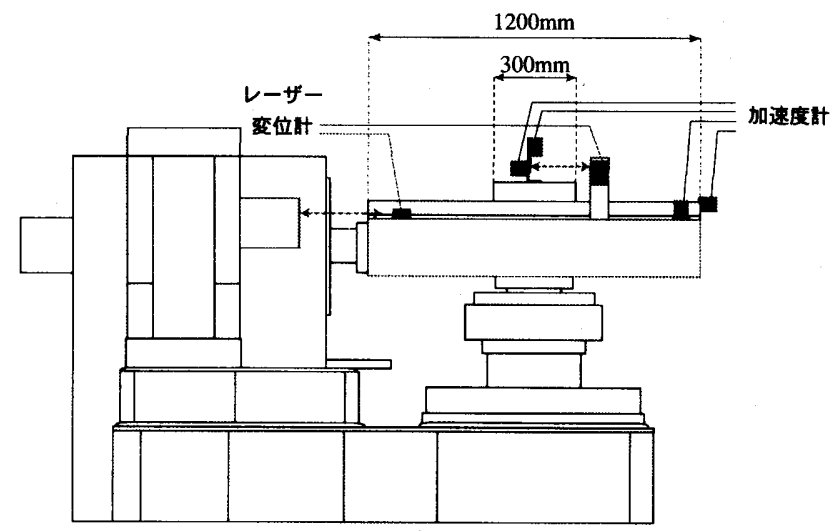

Fig. 1 实験装罾

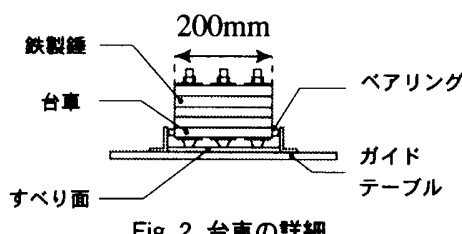

Table 1 台車の亚盘

Fig. 2 台車の詳細

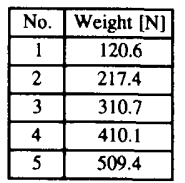

Table 2 実験パラメータ

\begin{tabular}{|c|c|c|}
\hline & No lubrication & Lubrication \\
\hline JMA KOBE NS & KOBE NS-no-1 15 & KOBE NS-lub-1 5 \\
\hline JMA KOBE EW & KOBE EW-no-1 $\sim 5$ & KOBE EW-lub-1 5 \\
\hline El Centro NS & EL NS-no-1 -5 & EL NS-lub-1 5 \\
\hline
\end{tabular}

（衰中の 1〜 5は Table 1の台車の各百量に対応する 番号を衰す)

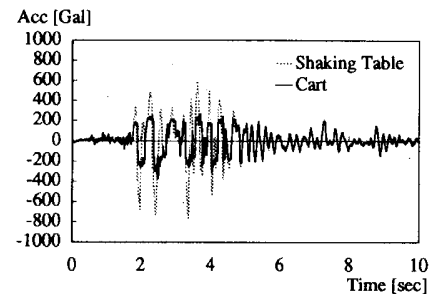

(a) 洞滑用なし

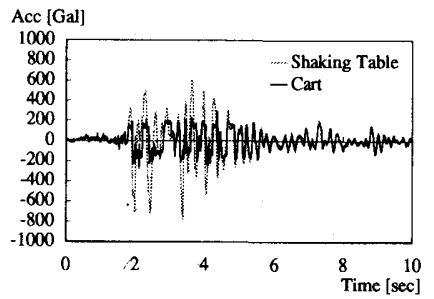

(b) 酒滑剂あり
Fig. 3 加速度時刻歴応答

(修正 JMA KOBE NS 入力時、台車の重 120.6N)

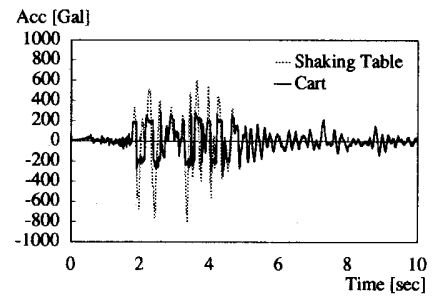

(a) 婳滑郕なし

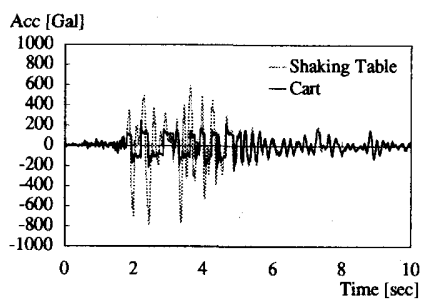

(b) 沕沙绪あり
Fig. 4 加速度時刻歷応答 (徏正 JMA KOBE NS 入力時、台車の重 $509.4 \mathrm{~N}$ ) 


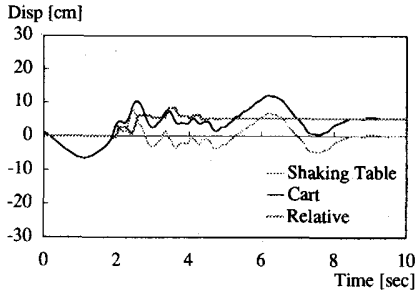

(a) 潤滑剂なし

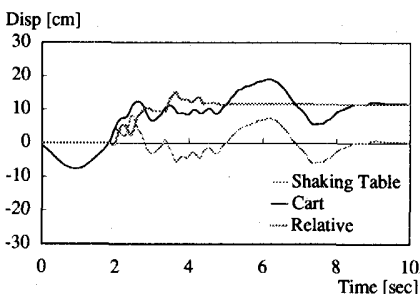

(b) 润滑堉あり
Fig. 5 変位時刻歴応答

（修正 JMA KOBE NS 入力、台車の重量 120.6N）

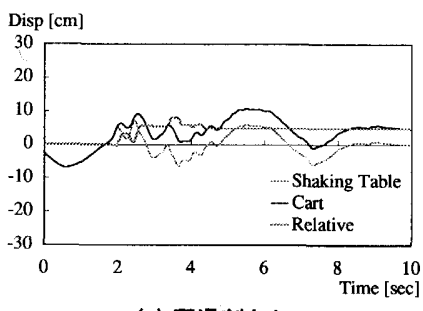

(a) 洞滑刜なし

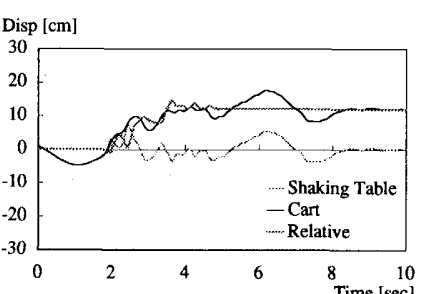

(b) 润滑用あり
Fig. 6 変位時刻歴応答

（修正 JMA KOBE NS 入力時、台車の重量 509.4N)

Table 3 実験結果

\begin{tabular}{|c|c|c|c|c|c|c|c|}
\hline & \multicolumn{2}{|c|}{ Max. Acc. } & \multicolumn{3}{|c|}{ RMS Acc. } & \multirow{2}{*}{$\begin{array}{l}\text { Max. } \\
\text { Disp. of } \\
\text { Cart } \\
{[\mathrm{cm}]}\end{array}$} & \multirow{2}{*}{$\begin{array}{c}\text { Residual } \\
\text { Disp. of } \\
\text { Cart } \\
\text { [cm] }\end{array}$} \\
\hline & $\begin{array}{c}\text { Shaking } \\
\text { Table } \\
\text { [Gal] } \\
\end{array}$ & $\begin{array}{l}\text { Cart } \\
\text { [Gal] }\end{array}$ & $\begin{array}{c}\text { Shaking } \\
\text { Table } \\
\text { [Gal] }\end{array}$ & $\begin{array}{c}\text { Cart } \\
\text { [Gal] }\end{array}$ & $\begin{array}{c}\text { Cart / } \\
\text { Shaking } \\
\text { Table }\end{array}$ & & \\
\hline KOBE NS-no-1 & 764 & 388 & 163 & 110 & 0.671 & 8.76 & 5.57 \\
\hline KOBE NS-no-2 & 770 & 295 & 164 & 105 & 0.639 & 9.55 & 5.16 \\
\hline KOBE NS-no-3 & 767 & 314 & 163 & 114 & 0.700 & 9.06 & 6.06 \\
\hline KOBE NS-no-4 & 806 & 375 & 164 & 114 & 0.696 & 8.76 & 5.92 \\
\hline KOBE NS-no-5 & 814 & 357 & 167 & 116 & 0.694 & 8.35 & 4.97 \\
\hline KOBE NS-lub-1 & 781 & 285 & 163 & 96 & 0.588 & 14.86 & 10.86 \\
\hline KOBE NS-lub-2 & 758 & 233 & 162 & 87 & 0.537 & 14.24 & 9.76 \\
\hline KOBE NS-lub-3 & 784 & 229 & 163 & 85 & 0.522 & 14.88 & 11.00 \\
\hline KOBE NS-lub-4 & 782 & 263 & 164 & 85 & 0.516 & 16.72 & 13.13 \\
\hline KOBE NS-lub-5 & 790 & 249 & 164 & 82 & 0.502 & 15.56 & 12.30 \\
\hline KOBE EW-no-1 & 670 & 281 & 132 & 97 & 0.733 & 4.25 & 4.20 \\
\hline KOBE EW-no-2 & 675 & 300 & 131 & 105 & 0.801 & 4.25 & 4.19 \\
\hline KOBE EW-no-3 & 662 & 281 & 133 & 102 & 0.766 & 4.22 & 4.18 \\
\hline KOBE EW-no-4 & 665 & 364 & 131 & 108 & 0.823 & 4.67 & 4.60 \\
\hline KOBE EW-no-5 & 684 & 369 & 133 & 107 & 0.810 & 4.54 & 4.49 \\
\hline KOBE EW-lub-1 & 671 & 242 & 133 & 90 & 0.679 & 6.92 & 5.70 \\
\hline KOBE EW-lub-2 & 681 & 215 & 134 & 87 & 0.648 & 7.11 & 6.25 \\
\hline KOBE EW-lub-3 & 667 & 216 & 133 & 83 & 0.625 & 7.22 & 6.11 \\
\hline KOBE EW-lub-4 & 660 & 237 & 132 & 86 & 0.647 & 7.30 & 6.09 \\
\hline KOBE EW-lub-5 & 669 & 236 & 133 & 81 & 0.609 & 7.23 & 5.97 \\
\hline EL NS-no-1 & 761 & 449 & 134 & 120 & 0.895 & 1.22 & 0.85 \\
\hline EL NS-no-2 & 678 & 318 & 122 & 107 & 0.882 & 1.30 & 0.07 \\
\hline EL NS-no-3 & 698 & 402 & 124 & 116 & 0.935 & 1.21 & 0.51 \\
\hline EL NS-no-4 & 693 & 344 & 123 & 107 & 0.869 & 1.71 & 0.48 \\
\hline EL NS-no-5 & 702 & 394 & 123 & 110 & 0.892 & 1.26 & 0.30 \\
\hline EL NS-lub-1 & 696 & 211 & 121 & 91 & 0.749 & 3.32 & 2.35 \\
\hline EL NS-lub-2 & 666 & 232 & 121 & 92 & 0.761 & 4.26 & 3.11 \\
\hline EL NS-lub-3 & 697 & 227 & 122 & 89 & 0.723 & 4.72 & 3.14 \\
\hline EL NS-lub-4 & 682 & 251 & 122 & 89 & 0.725 & 4.00 & 2.50 \\
\hline EL NS-lub-5 & 689 & 266 & 122 & 89 & 0.727 & 4.23 & 2.65 \\
\hline
\end{tabular}

車の加速度の RMS 值)/(振動台の加速度のRMS 值)]の結果から潤滑剤 を塗布したすべり面では、全般的に面圧が高くなるに従い台車の加速 度は小さくなる傾向にあることが他の入力波についても言える。

\section{3. 剛体モデルの実験結果による摩擦係数の同定}

\section{3-1 同定に用いる通動方程式}

実験で得られたデー夕を用いて摩擦係数の同定を行う。運動方程式 は式(1)とする。

$$
m \ddot{x}+\operatorname{sgn}(\dot{x}) \mu m g=-m \ddot{x}_{g}
$$

ここで $m$ は台車の質量、 $x$ は振動台と台車の相対変位、 $\mu$ は摩擦係数、 $g$
は重力加速度、 $\ddot{x}_{g}$ は入力加速度である。摩擦係数山は速度依存性を考 慮し、静止摩擦係数 $\mu_{s}$ 、動摩擦係数 $\mu_{d}$ 、指数減衰定数 $c に よ り$ 表され た式(2) (4) で仮定する ${ }^{8)}$ 。

$\dot{x}_{\lim }<|\dot{x}|$ の時 $\quad \mu=\mu *$

$|\dot{x}| \leq \dot{x}_{\text {lim }}$ の時

$$
\mu=\sin \left(\frac{\pi}{2} \cdot \frac{|\dot{x}|}{\dot{x}_{\lim }}\right) \cdot \mu *
$$

$$
\mu^{*}=\mu_{d}+\left(\mu_{s}-\mu_{d}\right) \exp (-c|\dot{x}|)
$$

ここで $\dot{x}$ は相対速度である。 $\dot{x}_{\mathrm{lim}}$ は $\dot{x}=0$ 前後で摩擦係数の值が急変

し、数値計算が不安定になることを防ぐ為に仮定した值であり、

$\dot{x}_{\text {lim }}=1.0$ kine とした。式(2) (4) で表される 示す。末知パラメーター $\mu_{s}, \mu_{d}, c$ を変数 $\mathbf{p}=\left\{p_{1}, p_{2}, p_{3}\right\}^{T}\left(p_{1}=\mu_{s}, p_{2}=\mu_{d}\right.$, $\left.p_{3}=c\right)$ とおき、 $k$ 番目の試行パラメータを $\mathbf{p}^{k}$ とすると、Newmark $\beta$ 法により $\mathbf{p}^{k}$ に対 応する応答 $\left(x_{\mathrm{i}}{ }^{k}, \ddot{x}_{\mathrm{i}}{ }^{k}\right)$ が求まる。ここでタ一 ゲット関数を式(5) とする。

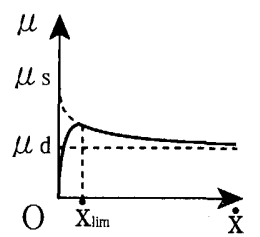

$$
f\left(\mathbf{p}^{k}\right)=\Sigma\left(x_{i}^{*}-x_{i}^{k}\right)^{2}\left(\ddot{x}_{i}^{*}-\ddot{x}_{i}^{k}\right)^{2}
$$
$x_{i}^{*}, x_{i}^{k}$ はそれぞれ実験で観測した相対変位 擦係数 $\mu$ との閶係 及び $k$ 番目の試行パラメータを用いて Newmark $\beta$ 法により得られた相 対変位を表す。添字 $i$ は時刻 $t=\Delta t \cdot i\left(\Delta t\right.$ は時間刻み)を意味する。 $f\left(\mathbf{p}^{k}\right)$ を最小化することにより、 $\mu_{s}, \mu_{d}, c$ を同定することができ、最小化手 法には次に示す減速ニュートン法を用いた。

\section{3-2 隇速ニュートン法}

ニュートン法は、変数 $\mathbf{x}=\left\{x_{1}, \cdots, x_{n}\right\}^{T}$ の関数 $f(\mathbf{x})$ の極小值を求め る方法であり、極小值 の近似值 $\mathbf{x}^{k}$ の近傍で $\Delta \mathbf{x}$ の変化があれば、関 数 $f$ の変化 $\Delta f$ は次式 2 番目の右辺で近似される。

$$
\begin{aligned}
\Delta f & \equiv f\left(\mathbf{x}^{k}+\Delta \mathbf{x}\right)-f\left(\mathbf{x}^{k}\right) \\
& =\mathbf{g}^{T}\left(\mathbf{x}^{k}\right) \Delta \mathbf{x}+\frac{1}{2}(\Delta \mathbf{x})^{T} \mathbf{H}\left(\mathbf{x}^{k}\right) \Delta \mathbf{x}
\end{aligned}
$$

ここに

$$
\left.\mathbf{g}\left(\mathbf{x}^{k}\right)=\left\{\frac{\partial f}{\partial x_{1}}, \frac{\partial f}{\partial x_{2}}, \cdots, \frac{\partial f}{\partial x_{n}}\right\}^{T} \quad \text { (勾配ベクトル }\right)
$$

$$
\mathbf{H}\left(\mathbf{x}^{k}\right)=\left[\begin{array}{cccc}
\frac{\partial^{2} f}{\partial x_{1}{ }^{2}} & \frac{\partial^{2} f}{\partial x_{1} \partial x_{2}} & \cdots & \frac{\partial^{2} f}{\partial x_{1} \partial x_{n}} \\
\frac{\partial^{2} f}{\partial x_{2} \partial x_{1}} & \frac{\partial^{2} f}{\partial x_{2}{ }^{2}} & \cdots & \frac{\partial^{2} f}{\partial x_{2} \partial x_{n}} \\
\cdots & \cdots & & \\
\frac{\partial^{2} f}{\partial x_{n} \partial x_{1}} & \frac{\partial^{2} f}{\partial x_{n} \partial x_{2}} & \cdots & \frac{\partial^{2} f}{\partial x_{n}{ }^{2}}
\end{array}\right]_{\mathbf{x = \mathbf { x } ^ { k }}} \text { (ヘシアン) }
$$

である。式(6)を最小化する $\Delta \mathbf{x}^{k}$ は、式(6)を微分することにより、次 式で与えられる。

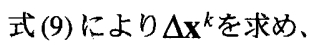

$$
\Delta \mathbf{x}^{k}=-\mathbf{H}^{-1}\left(\mathbf{x}^{k}\right) \mathbf{g}\left(\mathbf{x}^{k}\right)
$$

$$
\mathbf{x}^{k+1}=\mathbf{x}^{k}+\Delta \mathbf{x}^{k}
$$

として、次の点 $\mathbf{x}^{k+1}$ を決定し、 $\Delta \mathbf{x}^{k}$ が十分小さな值になるまで繰り返 し、極小值を求める方法がニュートン法と呼ばれるものである。この 方法では解が発散する場合が多く、今回はこれを少し改良し 


$$
\mathbf{x}^{k+1}=\mathbf{x}^{k}+0.1 \Delta \mathbf{x}^{k}
$$

とし、減速ニュートン法と名付けた。また、収斂条件は

$$
\left\|\mathbf{x}^{k}-\mathbf{x}^{k+1}\right\|_{\infty}<\varepsilon \cdot \max \left\{1,\left\|\mathbf{x}^{k}\right\|_{\infty}\right\}
$$

であり、ここで

$$
\|\left.\mathbf{x}^{k}\right|_{\infty}=\max \left\{\left|x_{1}{ }^{k}\right|,\left|x_{2}{ }^{k}\right|, \cdots,\left|x_{n}{ }^{k}\right|\right\}
$$

である。また、とは十分小さい值とする。本論における同定では $\varepsilon=1.0 \times 10^{-6}$ とした。

\section{3-3 同定結果及び考察}

同定結果を Table 4に、摩擦係数の散布図を Fig. 8 に示す。潤滑剤を 塗布しないすべり面の静止摩擦係数 $\mu_{s}$ は 0.08 0.21、動摩擦係数 $\mu_{d}$ は 0.17 0.36、潣滑剤を鉒布したすべり面の静止摩擦係数 $\mu_{s}$ は0.09 0.19、 動摩擦倸数 $\mu_{d}$ は0.03 0.20 と、かなりばらついた。潤滑剤を塗布した すべり面の動摩擦係数は塗布しないすべり面の動摩擦倸数より、全て のケースにおいて小さくなっている。潤滑剤を塗布しないすべり面は 台車の重量が大きくなる程やや静止摩擦係数が増加し、閵滑剤を塗布 したすべり面は台車の重量が大きくなる程若干動摩擦係数が減少して いるようにも見えるが、台車の重量による顕著な影貔はほとんど認め られない。次に同定結果の精度を調べるために 実験による応答と同定 された摩擦係数を用いた応答との比較を行い、その一例を Fig. 9 に示

Table 4 同定赫果

\begin{tabular}{|c|c|c|c|c|c|c|c|}
\hline & $\mu \mathrm{s}$ & $\mu \mathrm{d}$ & $\mathrm{c}$ & & $\mu \mathrm{s}$ & $\mu \mathrm{d}$ & $\mathrm{c}$ \\
\hline KOBE NS-no-1 & 0.119 & 0.213 & 0.217 & KOBE NS-lub-1 & 0.190 & 0.105 & 0.144 \\
\hline KOBE NS-no-2 & 0.160 & 0.169 & 0.125 & KOBE NS-lub-2 & 0.150 & 0.051 & 0.052 \\
\hline KOBE NS-no-3 & 0.149 & 0.222 & 0.200 & KOBE NS-lub-3 & 0.135 & 0.073 & 0.076 \\
\hline KOBE NS-no-4 & 0.152 & 0.175 & 0.103 & KOBE NS-lub-4 & 0.137 & 0.028 & 0.032 \\
\hline KOBE NS-no-5 & 0.169 & 0.213 & 0.379 & KOBE NS-lub-5 & 0.140 & 0.064 & 0.077 \\
\hline KOBE EW-no-1 & 0.163 & 0.244 & 0.076 & KOBE EW-lub-1 & 0.108 & 0.159 & 0.124 \\
\hline KOBE EW-no-2 & 0.170 & 0.220 & 0.146 & KOBE EW-lub-2 & 0.123 & 0.129 & 0.112 \\
\hline KOBE EW-no-3 & 0.205 & 0.276 & 0.056 & KOBE EW-lub-3 & 0.105 & 0.140 & 0.048 \\
\hline KOBE EW-no-4 & 0.213 & 0.209 & 0.074 & KOBE EW-lub-4 & 0.115 & 0.136 & 0.102 \\
\hline KOBE EW-no-5 & 0.197 & 0.238 & 0.104 & KOBE EW-lub-5 & 0.113 & 0.139 & 0.061 \\
\hline EL NS-no-1 & 0.280 & 0.294 & 0.461 & EL NS-lub-1 & 0.112 & 0.158 & 0.185 \\
\hline EL NS-no-2 & 0.082 & 0.277 & 0.323 & EL NS-lub-2 & 0.145 & 0.201 & 0.012 \\
\hline EL NS-no-3 & 0.090 & 0.356 & 0.448 & EL NS-lub-3 & 0.100 & 0.130 & 0.112 \\
\hline EL NS-no-4 & 0.098 & 0.248 & 0.489 & EL NS-lub-4 & 0.104 & 0.151 & 0.130 \\
\hline EL NS-no-5 & 0.173 & 0.282 & 0.408 & EL NS-lub-5 & 0.093 & 0.100 & 0.100 \\
\hline & & & & & & &
\end{tabular}

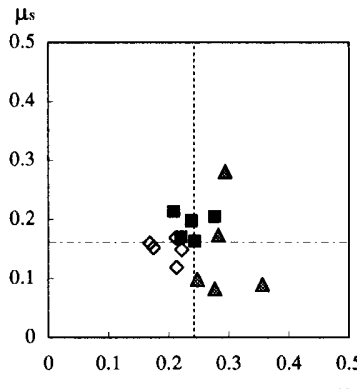

(a) 润滑绪なし

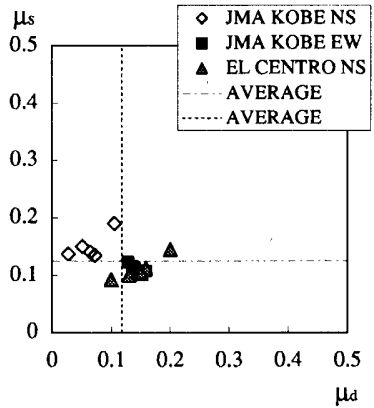

(b) 洞滑都あり
Fig. 8 舞擦係数の数布图

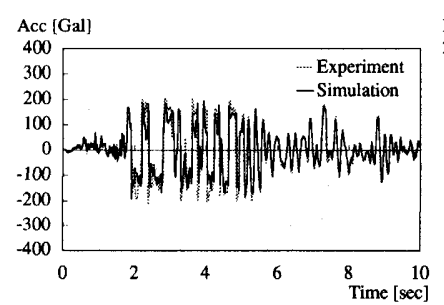

(a) 加速度

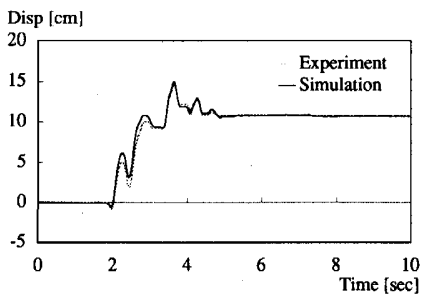

(b) 变位
Fig. 9 実検と解析の応答の比較
す。このグラフよりシミュレーション結果は夷験結果をよく再現出来 ていると言える。

\section{4. 多質点系モデルによる振動実験 \\ 4-1 実験装昔と実験方法}

次にすべり面を有するガイドテーブルを振動台の上に固定し、すべ り面の上に 3 層フレームを載せ (Fig. 10)、振動実験を行った。柱の剛 性の異なる2種類の3層フレームModel-1(剛性小)、Model-2(剛性大)を 用い、それぞれの重量と剛性を Table 5 に示す。入力する地震波は 2. の実験で用いた地震波と同じく、修正 JMA KOBE 波と修正 El Centro NS 波とする。3 層フレームを、1）振動台に固定した場合、2）潤滑剂 を塗布しない滑り面上に載せる場合、3) 潤滑剤を塗布した滑り面上に 載せる場合、の3 種類の異なる設置条件について実験を行った。2.の 実験と同様、潤滑剤として有機モリブデンを用いた。モデル、地震波、 設置条件をパラメータとし計18ケース(Table 6)について3回ずつ実験 を絽り返し、各層の絶対加速度と層間変位を加速度計とレーザー変位 計により計測した。

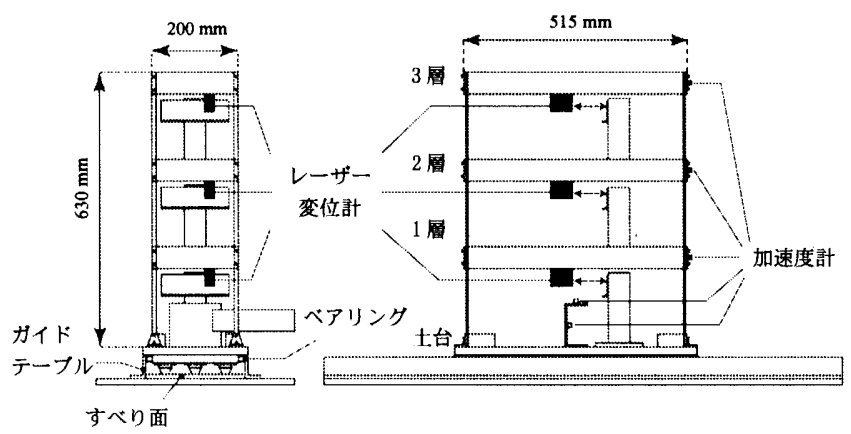

Fig. 10 实殹装再

Table 5 フレームの重量と䦌性

\begin{tabular}{|c|c|c|c|c|}
\hline & \multicolumn{2}{|c|}{ Model-1 } & \multicolumn{2}{c|}{ Model-2 } \\
\cline { 2 - 5 } & $\begin{array}{c}\text { Weight } \\
{[\mathrm{N}]}\end{array}$ & $\begin{array}{c}\text { Stiffness } \\
{[\mathrm{N} / \mathrm{cm}]}\end{array}$ & $\begin{array}{c}\text { Weight } \\
{[\mathrm{N}]}\end{array}$ & $\begin{array}{c}\text { Stiffness } \\
{[\mathrm{N} / \mathrm{cm}]}\end{array}$ \\
\hline 3rd Floor & 54.1 & 316.1 & 54.1 & 749.3 \\
\hline 2nd Floor & 69.6 & 316.1 & 69.6 & 749.3 \\
\hline 1st Floor & 73.5 & 316.1 & 73.5 & 749.3 \\
\hline Base & 256.8 & 0.0 & 256.8 & 0.0 \\
\hline
\end{tabular}

Table 6 实䤲パラメータ

\begin{tabular}{|c|c|c|c|}
\hline & Fixed & $\begin{array}{c}\text { Sliding } \\
\text { / No Lubrication }\end{array}$ & $\begin{array}{c}\text { Sliding } \\
\text { / Lubrication }\end{array}$ \\
\hline JMA KOBE NS & KOBE NS- fix-M1,2 & KOBE NS- no- M1, 2 & KOBE NS- lub- M1.2 \\
\hline JMA KOBE EW & KOBE EW- fix-M1, 2 & KOBE EW- no- M1, 2 & KOBE EW- lub- M1, 2 \\
\hline El Centro NS & EL NS- fix-M1,2 & EL NS- no- M1, 2 & EL NS- lub-M1, 2 \\
\hline
\end{tabular}

(M1 は Model-1, M2 は Model-2 を示す)

\section{4-2 実験結果及び考察}

Model-1 に修正 JMA KOBE NS 波を入力した場合の層間変位の時刻 歴応答の一部を Fig. 11 に示す。Fig. 11 の (a) は 1 層の層間変位であり、 細線は固定した場合、実線は潤滑剤を塗布したすべり面に載せた場合 を示している。潤滑剤を塗布したすべり面に載せた場合は固定した場 合と比較して層間変位が大幅に隇少し、最大值は固定した場合の $25 \%$ 以下にまで低減された。また Fig. 11 の (b) の細線は固定した場合の土 台変位(= 振動台の変位)、太線は潤滑剤を塗布したすべり面に載せた 場合の土台変位(=すべり量)を示している。実験結果のまとめを Table 7 に示す。それぞれの值は 3 回の繰り返しの平均值である。すべり量 は地震波や潤滑剤の有無によりばらつきがあり、最大すべり量は $11 \mathrm{~cm}$ 


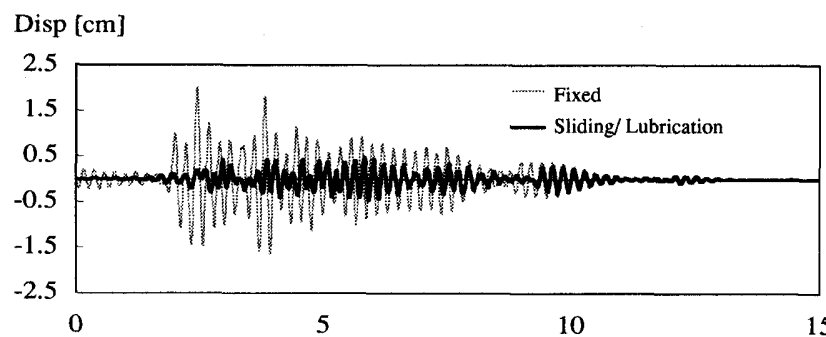

(a) 1 周層間变位
Disp [cm]

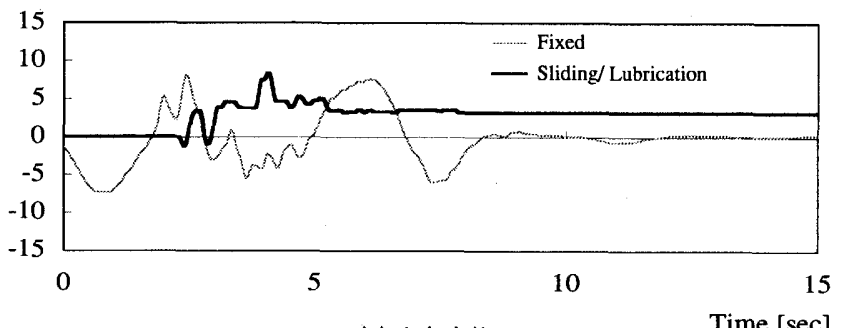

(b) 土台変位

Time [sec]

Fig. 11 実験結果 变位時刻歴応答（Model-1 に修正 JMA KOBE NS を入力）

Table 7 実験結果

\begin{tabular}{|c|c|c|c|c|c|c|c|c|c|c|}
\hline & $\begin{array}{c}\text { Max. Acc. } \\
\text { of Shaking } \\
\text { Table [Gal] }\end{array}$ & $\begin{array}{c}\text { Max. Acc. } \\
\text { of Base } \\
\text { [Gal] }\end{array}$ & $\begin{array}{c}\text { Max. Acc. } \\
\text { of 1F [Gal] }\end{array}$ & $\begin{array}{c}\text { Max. Acc. } \\
\text { of 2F [Gal] }\end{array}$ & $\begin{array}{c}\text { Max. Acc. } \\
\text { of 3F [Gal] }\end{array}$ & $\begin{array}{c}\text { Max. Disp. } \\
\text { of Base } \\
\text { [cm] }\end{array}$ & $\begin{array}{c}\text { Residual } \\
\text { Disp. of } \\
\text { Base [cm] }\end{array}$ & $\begin{array}{c}\text { Max. Inter- } \\
\text { story Disp. } \\
\text { of 1F [cm] }\end{array}$ & $\begin{array}{c}\text { Max. Inter- } \\
\text { story Disp. } \\
\text { of 2F [cm] }\end{array}$ & $\begin{array}{c}\text { Max. Inter- } \\
\text { story Disp. } \\
\text { of 3F [cm] }\end{array}$ \\
\hline KOBE NS-fix-M1 & 853 & 848 & 2224 & 2675 & 2923 & 8.12 & - & 1.97 & 1.20 & 0.58 \\
\hline KOBE NS-no-M1 & 845 & 1957 & 1170 & 1336 & 1552 & 10.24 & 9.12 & 0.74 & 0.51 & 0.27 \\
\hline KOBE NS-lub-M1 & 850 & 585 & 640 & 924 & 1218 & 8.93 & 4.07 & 0.46 & 0.42 & 0.20 \\
\hline KOBE EW-fix-M1 & 653 & 666 & 746 & 2526 & 2927 & 6.93 & - & 1.77 & 1.22 & 0.60 \\
\hline KOBE EW-no-M1 & 673 & 2682 & 1268 & 1618 & 1738 & 1.54 & 1.08 & 0.70 & 0.60 & 0.38 \\
\hline KOBE EW-lub-M1 & 700 & 571 & 584 & 950 & 1156 & 5.80 & 5.08 & 0.55 & 0.44 & 0.21 \\
\hline EL NS-fix-M1 & 711 & 719 & 1723 & 1961 & 2187 & 5.26 & - & 1.20 & 0.80 & 0.38 \\
\hline EL NS-no-M1 & 794 & 1312 & 1326 & 1182 & 1858 & 4.27 & 4.12 & 0.63 & 0.48 & 0.29 \\
\hline EL NS-lub-M1 & 759 & 412 & 568 & 658 & 813 & 4.05 & 0.98 & 0.31 & 0.24 & 0.14 \\
\hline KOBE NS-fix-M2 & 788 & 808 & 1801 & 2006 & 2585 & 8.61 & - & 0.60 & 0.42 & 0.20 \\
\hline KOBE NS-no-M2 & 836 & 1308 & 998 & 1276 & 1416 & 10.24 & 9.73 & 0.25 & 0.20 & 0.10 \\
\hline KOBE NS-lub-M2 & 829 & 392 & 521 & 579 & 841 & 10.78 & 6.04 & 0.15 & 0.13 & 0.06 \\
\hline KOBE EW-fix-M2 & 640 & 655 & 1477 & 1810 & 2023 & 7.54 & - & 0.50 & 0.32 & 0.15 \\
\hline KOBE EW-no-M2 & 655 & 1037 & 966 & 1007 & 1169 & 2.89 & 2.38 & 0.26 & 0.17 & 0.08 \\
\hline KOBE EW-lub-M2 & 646 & 450 & 504 & 560 & 915 & 7.89 & 6.57 & 0.16 & 0.13 & 0.07 \\
\hline EL NS-fix-M2 & 692 & 705 & 1959 & 2072 & 2330 & 5.77 & - & 0.57 & 0.36 & 0.18 \\
\hline EL NS-no-M2 & 734 & 1386 & 1177 & 1122 & 1536 & 2.13 & 2.13 & 0.29 & 0.20 & 0.10 \\
\hline EL NS-lub-M2 & 742 & 496 & 617 & 713 & 1010 & 3.12 & 0.31 & 0.18 & 0.14 & 0.07 \\
\hline
\end{tabular}

程度、残留すべり量は $10 \mathrm{~cm}$ 程度となった。加速度は1 3 層において すべり面に載せた場合、固定した場合の30 50\%に低滅されている。 ただし潤滑剤を塗布しない場合において、土台の加速度が振動台の加 速度よりも大きくなっている。これらのケースでは上下方向の跳ね上 がりが目視されており、それが水平加速度計に何らかの影響を与えた ものと考えられる。

\section{3 層フレームの実験結果による摩擦係数の同定 5-1 同定に用いる運動方程式}

3層フレームの実験結果を用いて3.の場合と同様に、摩擦係数の同 定を行う。同定に用いる運動方程式を式(14)に示す。

$$
\mathbf{M} \ddot{\mathbf{x}}+\mathbf{C} \dot{\mathbf{x}}+\mathbf{K} \mathbf{x}+\left\{\begin{array}{c}
0 \\
0 \\
0 \\
\operatorname{sgn}\left(\dot{x}_{0}\right) \mu M_{\text {all }} g
\end{array}\right\}=-\mathbf{M}\left\{\begin{array}{l}
1 \\
1 \\
1 \\
1
\end{array}\right\} \ddot{x}_{g}
$$

ここでMは質量行列、 $x$ は相対変位、C は隇衰行列、 $\mathrm{K}$ は剛性行列、 $\mu$ は摩擦係数、 $M_{\text {all }}$ は全質量、 $\ddot{x}_{g}$ は入力加速度である。減衰行列は剛性 比例型とし、Model-1においては剛性行列の $0.175 \%$, Model-2において は $0.1 \%$ とした。これらの值は台車を振動台に固定した場合の応答を 最もよく近似する值を選んだものである。固定した場合は各層剛性の $3 \supset\left(k_{1}, k_{2}, k_{3}\right)$ を、固定しない場合は各層剛性之摩擦係数の $6 \supset\left(k_{1}\right.$, $\left.k_{2}, k_{3}, \mu_{s}, \mu_{d}, c\right)$ をパラメータとし、同定を行った。同定のための最 小化するターゲット関数は式(15)とした。

$$
f\left(\mathbf{p}^{k}\right)=\sum_{i} \sum_{m}\left(x(m)_{i}{ }^{*}-x(m)_{i}^{k}\right)^{2}
$$

ここで $x(m)_{i}{ }^{*}, x(m)_{i}{ }^{k}$ はそれぞれ時刻 $t=\Delta t \cdot i$ た $m$ 層の層間変位及び $k$ 番目の試行パラメータを用いてシミュレー ションにより得られたm層の層間変位を表す。固定した場合は式(14) の免震層と摩擦力の項を取り除いて 3 自由度とし、すべりの場合は4 自由度として計算を行った。

\section{5-2 同定結果および考察}

各層の剛性の同定結果を Table 8に、Fig. 12に Table 8をグラフ化し たものを示す。剛性は実験条件による多少のばらつきが生じ、柱の形 状、材料のヤング係数から概算した值(Table 5)より小さくなるという 結果となった。静止摩擦係数 $\mu_{s}$ は 0.16 0.18、動摩擦係数 $\mu_{d}$ は 0.10 0.14 が得られた。3.の同定と比較して摩擦保数のばらつきが小さく なった。この理由としては3.の同定が 1 質点の変位と加速度のみを追 従すればよく、実際の摩擦係数とは異なる值であっても数值計算上、 ある程度つじつまを合わせることができてしまう可能性があるのに対 し、5.の同定においては、4質点の変位を追従するという厳しい条件 となったためであると考えられる。また潤滑剤を塗布しないすべり面 については台車の跳ね上がりが目視されていたため、式(14)の運動方 程式による同定は不適切と判断し、Table 9には潤滑剤を塗布したすべ り面のみの結果を載せている。Model-1 に修正 JMA KOBE NS 波を入 力した場合の層間変位の時刻歷応答の一部を Fig. 14(a) に示す。Fig. 14(a)のシミュレーション結果はFig. 11(a)の実験結果と対応しており、 
Table 8 同定結果 (各厢㓮性)

\begin{tabular}{|c|c|c|c|}
\hline & $1 \mathrm{~F}[\mathrm{~N} / \mathrm{cm}]$ & $2 \mathrm{~F}[\mathrm{~N} / \mathrm{cm}]$ & $3 \mathrm{~F}[\mathrm{~N} / \mathrm{cm}]$ \\
\hline KOBE NS-fix-M1 & 263.9 & 275.7 & 282.7 \\
\hline KOBE EW-fix-M1 & 257.4 & 272.1 & 292.4 \\
\hline EL NS-fix-M1 & 266.9 & 268.4 & 279.5 \\
\hline KOBE NS-lub-M1 & 258.1 & 268.1 & 271.2 \\
\hline KOBE EW-lub-M1 & 261.0 & 279.0 & 272.2 \\
\hline EL NS-lub-M1 & 281.3 & 269.8 & 272.5 \\
\hline KOBE NS-fix-M2 & 573.9 & 612.4 & 636.6 \\
\hline KOBE EW-fix-M2 & 562.6 & 613.3 & 634.0 \\
\hline EL NS-fix-M2 & 557.4 & 624.2 & 608.3 \\
\hline KOBE NS-lub-M2 & 582.5 & 599.5 & 616.8 \\
\hline KOBE EW-lub-M2 & 586.1 & 615.3 & 629.7 \\
\hline EL NS-lub-M2 & 599.5 & 593.0 & 574.5 \\
\hline
\end{tabular}

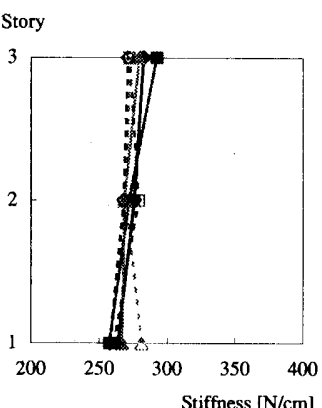

(a) Model-1

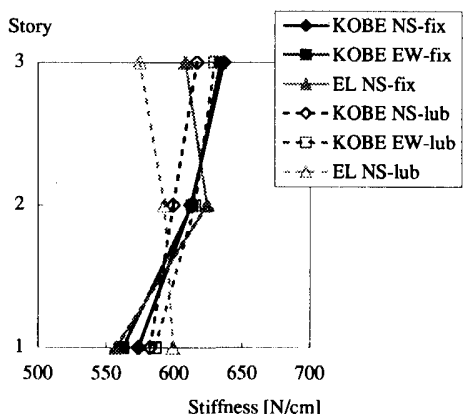

(b) Model-2
Fig. 12 各届㓮性

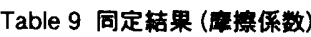

\begin{tabular}{|c|c|c|c|}
\hline & $\mu \mathrm{s}$ & $\mu \mathrm{d}$ & $\mathrm{c}$ \\
\hline KOBE NS-lub-M1 & 0.161 & 0.142 & 0.190 \\
\hline KOBE EW-lub-M1 & 0.180 & 0.097 & 0.101 \\
\hline EL NS-lub-M1 & 0.159 & 0.132 & 0.121 \\
\hline KOBE NS-lub-M2 & 0.162 & 0.116 & 0.176 \\
\hline KOBE EW-lub-M2 & 0.181 & 0.101 & 0.139 \\
\hline ELNS-lub-M2 & 0.168 & 0.114 & 0.082 \\
\hline
\end{tabular}

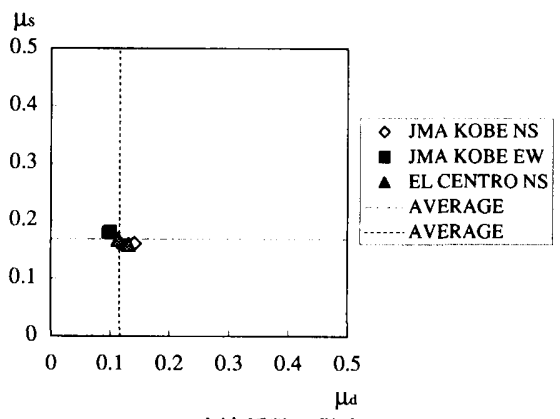

Disp [cm]

Fig. 13 㢈擦係数の数布図

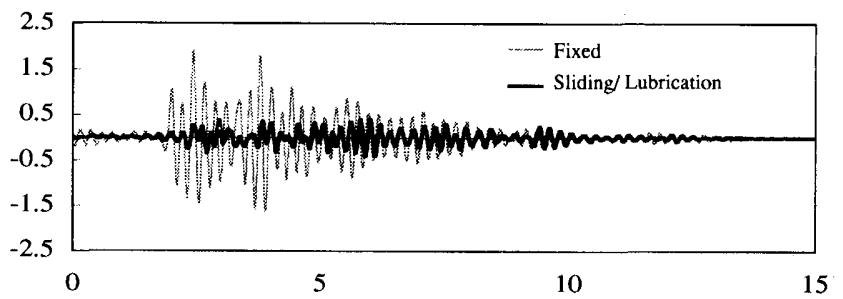

Disp [cm]

(a) 1 嵓用間変位

Time [sec]

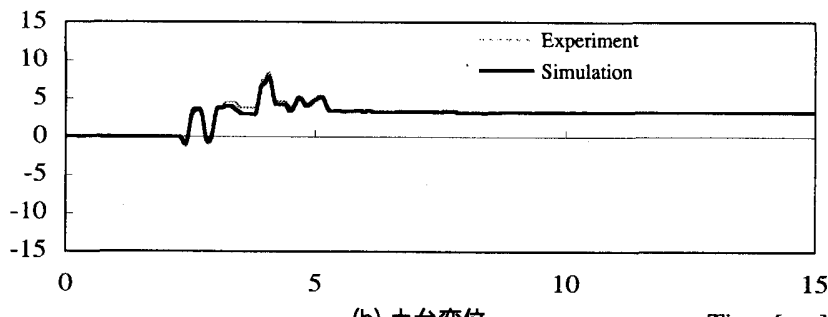

(b) 土台変位

Time [sec]

Fig. 14 解析結果 变位時刻歴応答 (Model-1 に修正 JMA KOBE NS を入力)
細線は固定した場合、太線は潤滑剤を塗布したすべり面に載せた場合 である。Fig. 14(b) は Model-1 に修正 JMA KOBE NS 波を入力した場合 の土台の変位時刻歴応答の実験とシミュレーションとの比較であり、 グラフの概形をある程度再現出来ていると言える。

\section{6. 結諭}

摩擦係数が 0.2 程度のステンレスを用いたすべり支承を想定した 2 種類の実験を行い、その有効性を検証した。まずステンレス製のすべ り面の上にステンレス製の重量可変の台車を載せ、時間圧縮した地震 動を入力する実験を行い、実験結果を用いて摩擦係数を同定した。そ の結果、すべり量は本実験で変化させた範囲においては、面圧に依存 しないこと、面圧が高くなるにつれ台車の応答加速度が小さくなるこ とが分かった。潤滑剤を塗布したすべり面の静止摩擦係数 $\mu_{s}$ は 0.09 0.19、動摩擦係数 $\mu_{d}$ は 0.03 0.20となり、面圧が高くなるにつれ て若干動摩擦係数が隇少する傾向にあった。次に台車の上に 3 層フ レームを載せた実験を行い、実験結果を用いて摩擦係数を同定し、静 止摩擦係数 $\mu_{s}$ は0.16 0.18、動摩擦係数 $\mu_{d}$ は0.10 0.14 と得た。ステン レスの摩擦係数の值がおよそ 0.2 であることを、実際に使用される状 態を想定した 2 種類の実験により確かめることが出来た。この值は 200Galを越えて初めてすべりが発生することを意味し、中小地震や強 風ではすべりが発生しにくくなる。よって中小地震や強風時でのすべ りを抑えるための装置が簡便な物になり、低価格化も期待できる。ま た 0.2 という摩擦係数でも各層の最大応答加速度は $50 \%$ 程度に、最大 層間変位は $25 \%$ 以下にまで低隇されることが分かった。尚、原波形を 用いての実験は本実験装膡では不可能であるが、摩擦係数が入力波形 にそれ程依存しないとすれば、それらの同定された摩擦係数と種々の 原波形を用いてのシミュレーションにより低滅効果や残留すべり量を ある程度評価できるものと考える。それらは今後の課題としたい。

\section{部辞}

本研究を進めるにあたり、関西電力株式会社にはご協力を得まし た。記して謝辞といたします。

\section{考考女献}

1) 富島誠司, 大橋智樹, 佐藤啓治 : すべり支承方式の免震に用いるすべり材の 動摩擦係数に関する研究, 日本建築学会技術報告集 No.1,pp.140 145, 1995.12 2) 日比野浩, 高木政美, 勝田庄二, 室田伸夫, 原暢彦 : 大口径弾性すべり支承の 摩撩特性試験(その3 載荷振幅が摩擦係数に及ほす影響), 日本建娼学会大会 学術講演梗概集 B-2 分冊, pp.503 504, 2002. 8

3) 江森純一,山中久幸, 谷垣政治, 平田裕一,山岸邦彰 : 弾性すべり支承の基本 性能に関する実験的研究，日本建築学会大会学術講演梗概集 B-2 分冊, pp.487 488, 1998. 9

4) 池内邦江, 村司真生, 橘英三郎 : すべり支承型免震構造の応答に関する一考 察，日本建築学会大会学術講演梗概集 B-2 分冊, pp.653 654, 2000. 9

5) 大山秀美, 三山网史, 增田圭司, 中山輝雄，鳥居次夫，上田栄, 河合俊直:滑り 支承を用いた免震構法の研究その1. 滑り支承の概要と鈶直性能, 日本建築学 会大会学術講演梗概集 B-2 分冊, pp. 691 692, 1999.9

6) 西村春美，小野聡子，橘英三郎：滑り型免震支承の摩擦係数に関する実験的 及び解析的研究(潤滑剤及び上下動が摩擦倸数に及ぼす影響), 日本建築学会大 会学術講演梗概集 B-2 分冊, pp.557 558, 2003.9

7) 西村春美,安部祥子, 橘英三郎：2 軸振動実験による金属面すべり支承の摩 擦係数の同定とそれによる応答低減効果, 第 54 回理論応用力学講演会講演論 文集 pp.575 576, 2005.1

8) The Japan Research Institute, Limited. LS-DYNA Ver.950 USER'S MANUAL 1999 